Research Report No. 35/2012

\title{
The Structure of the Indian Act: Accountability in Governance
}

Shin Imai

Osgoode Hall Law School of York University, simai@osgoode.yorku.ca

Follow this and additional works at: http:// digitalcommons.osgoode.yorku.ca/clpe

\section{Recommended Citation}

Imai, Shin, "The Structure of the Indian Act: Accountability in Governance" (2012). Comparative Research in Law \& Political Economy. Research Paper No. 35/2012.

http://digitalcommons.osgoode.yorku.ca/clpe/8 


\section{OSGOODE}

\section{OSGOODE HALL LAW SCHOOL}

Comparative Research in Law \& Political Economy

RESEARCH PAPER SERIES

Research Paper No. 35/2012

\section{The Structure of the Indian Act: Accountability in Governance}

Shin Imai

Editors:

Peer Zumbansen (Osgoode Hall Law School, Toronto, Director Comparative Research in Law and Political Economy)

John W. Cioffi (University of California at Riverside)

Leeanne Footman (Osgoode Hall Law School, Toronto, Production Editor)

Comparative Research in 


\title{
The Structure of the Indian Act: Accountability in Governance
}

\author{
Shin Imai \\ Osgoode Hall Law School \\ (July 30, 2007)
}

\section{Introduction}

The Indian Act has been criticized for giving the Chief and Council too little power to make their own decisions. The Royal Commission on Aboriginal Peoples counted nearly 90 provisions that give the Minister of Indian Affairs powers over the Band and Band Council. ${ }^{1}$

But the Indian Act has also been criticized for giving the Chief and Council too much power to make decisions. Some people point out that Chief and Council do not have enough accountability to members of the community. In sum, the Indian Act is criticized for giving Chief and Council too little authority and with giving Chief and Council too much authority.

The fact is, both criticisms are valid. We will see in the discussion on the following pages how the structure of the Indian Act creates this contradictory state of affairs. We will discuss how to avoid such contradictions when the First Nation moves out of the Indian Act to a more suitable First Nation designed government system.

It is impossible to analyze every section of the Indian Act. Instead, we will focus on the accountability structure in the

One problem with the Indian Act - power flows one way

Federal Government

Chief and Council $\uparrow$

Community members Indian Act in three areas where the Chief and Council can exercise some authority: allocation of reserve land, First Nation law-making powers and custom elections.

These three areas affect the lives of members of the community very directly. Under the Indian Act, the federal government has the power to overrule decisions of Chief and Council. But Chief and Council also have powers that can be exercised without input from the community. By studying who has the power to do what in these areas we will be able to see the balance in the powers of Chief and Council, members of the community and the federal government.

A government system designed by First Nations will see a much reduced or eliminated role for the federal government. But this will not be enough. The First Nation government system should also deal with ways to ensure that Chief and Council use their powers in a good way. There are three ways to control the powers of Chief and Council.

First, Chief and Council should be accountable to the community members. This means that 
there should be some form of community participation in the making of laws. Of course, this cannot mean that every decision of Chief and Council must be approved at a community meeting. That would make it impossible to govern. But it does mean that Chief and Council should have a policy that distinguishes routine decisions, which do not require consultation, from important decisions that should involve the whole community.

Second, the decisions of Chief and Council should be consistent with core principles that are important to the community. In the mainstream community, these core principles are found in the Charter of Rights and Freedoms, which protects freedom religion, prohibits discrimination and guarantees fair trials. Aboriginal communities could develop other core principles, such as respect for culture, which could be set out in a First Nation constitution.

Third, there must be a tribunal that is independent of Chief and Council that can certify and interpret the laws and can hear appeals from decisions. This tribunal can determine whether the Chief and Council have authority to make the laws, whether there has been adequate community participation and whether the laws are consistent with the First Nation's core principles. Under the Indian Act, the Minister of Indian Affairs and the courts carry out this function. Under a First Nation governance regime, an independent tribunal made up of First Nation people could carry out this function.

In the next section, we will see how the three accountability mechanisms mentioned above operate in the Indian Act.

\section{The Exercise of Power by the Federal Government and by Chief and Council}

The Chief and Council have powers to make decisions that affect the lives of community members. In the parts of the Indian Act that are the oldest, the Chief and Council could make decisions without consulting with anyone. For example the Indian Act does not give any guidance on how the Chief and Council are to decide on how to give out certificates of possession on reserve. The older parts of the Indian Act also give the government very wide powers to override decisions of Chief and Council. For example, if the Chief and Council decide to give out a certificate of possession, the Minister of Indian Affairs can override that decision and refuse to approve the certificate of possession.

We will see in the discussion below that the newer parts of the Indian Act make some changes to increase community participation. For example, in order for the Band to take control of its own membership, there must be approval from the majority of the people who are allowed to vote. The newer parts of the Indian Act also reduce the power of the federal government. If the majority of the voters of a First Nation approve a new membership code, for example, the federal government cannot override the decision. ${ }^{2}$

\section{Allocation of land on reserve}

Three examples of the use of power

1. Allocation of reserve lands

- Certificates of possession

- Band-owned housing

2. Band Council powers to make bylaws

- General by-laws

- Alcohol by-laws

- Membership codes

3. First Nation custom elections 
The Chief and Council can make a variety of decisions under the Indian Act. These decisions are usually implemented through a B.C.R. (Band Council Resolution). Some decisions are administrative, such as signing routine contracts, while other decisions affect First Nation members and the First Nation as a whole. The Indian Act fails to provide guidance on how these decisions are to be made. To illustrate the issue, I will outline the accountability structure for decisions on allotment of land and allocation of Band housing.

Some reserve land is allotted to private individuals who are given certificates of possession (section 20). Once these certificates are issued, the owner has private property rights to the land and can sell it or leave it in a will to another Band member. In order to receive a certificate of possession, the Band member must receive approval from the Band Council and receive approval from the Minister of Indian Affairs. ${ }^{3}$ There is nothing in the Indian Act that provides guidelines to the Chief and Council, nor to the Minister, on the basis for handing out certificates of possession.

The certificate of possession system was established in the last century as part of the campaign to "civilize" Indians by moving them away from their communal land sharing customs towards a private property regime. Many First Nations have resisted giving out certificates of possession and instead rely on their own laws and customs to allocate lands. For example, the Band will often determine who should live in Band housing. Most Bands have developed housing policies to ensure fairness. They will not allow an individual to rent out the housing or leave it empty if there are other people on the waiting list. However, there is nothing in the Indian Act, which recognizes this form of land allocation ${ }^{4}$ so there is nothing in the Indian Act which makes it mandatory for Chief and Council to develop fair housing policies.

In dealing with possession of land on reserve, then, we see that Chief and Council have quite a lot of authority. They can decide who should get certificates of possession or who gets Band housing. There is nothing in the Indian Act that discusses the responsibility of Chief and Council to the community or allowing community participation in the decisions. ${ }^{5}$

\section{Band Council powers to make by-laws}

The Band Council has authority to make four different types of by-laws. In each type, there is a different balance among the Chief and Council, the community and the federal government.

The general by-law making power (section 81) lists 22 subjects areas ranging from a very broad power over "observance of law and order" to a very minor jurisdiction over the control of "noxious weeds". The Chief and Council can pass a by-law with a majority vote in a council meeting. There is no requirement to publish the proposed by-law in advance or to inform community members that a vote will be taking place. After the vote, the Band Council must send the by-law to the Minister who may disallow any by-law within forty days. In the past the disallowance rate was very high. The Minister is not required to give any reasons for disallowing the by-law. ${ }^{6}$ 
There is a slightly different method for making by-laws dealing with taxation and other financial matters (section 83). Under this section the Band Council can tax their own members and pay Band expenses out of Band moneys. There is no requirement that the Band Council consult its members. The Minister must approve these by-laws before they are effective.

A third method is set out for passing by-laws banning alcohol on reserves (section 85.1). To pass such a by-law, the Band Council needs to call a special meeting at which the majority of electors vote in favour of the by-law. The by-law is then sent to the Minister of Indian Affairs . The Minister does not have any power to disallow this by-law if the proper procedure was followed.

A fourth method is used for making Band membership codes (section 10). To pass its own membership code, a Band must give notice to its members that it intends to pass a code. The code requires the approval of the majority of the members who are qualified to vote - not just the majority of people who come out to vote. This means that half of the adult members of the Band must give their approval. This is a very high standard. If there are 1,000 eligible voters, you need 501 people to vote in favour. Let us say that 750 people decide to vote on the issue. If 450 vote in favour and 300 vote against, the code will not pass, because you need 501 people to vote in favour. Once the approvals are obtained, the Band must send the code to the Minister. If the Minister is satisfied that the process has been followed, the Minister declares that the Band has control of its membership.

Looking at these four methods for making by-laws we can see that there is a progression in the balance of power. The general by-law making power (section 81 ) and the money by-law making power (section 83) were enacted in 1951. They give the Minister wide powers to allow or disallow the by-law. They do not require the Band Council to inform or consult with their own members. New law-making provisions inserted in the 1980's introduced changes to the process. The alcohol control by-law and the membership code require greater participation by members of the First Nation and reduce the authority of the Minister of Indian Affairs to disallow these bylaws.

\section{First Nation Custom Elections}

The governance of reserve communities is very important and disputes about elections can be very bitter. Traditionally, First Nations chose their leaders in different ways - in some First Nations, it was hereditary, and in others there was a selection process. In order to "assimilate" Indians, the Indian Act gave the government the power to override traditional methods of governance. In the case of Six Nations in Ontario, for example, the government used its power to overthrow the traditional Haudenosaunee Council in 1924 and replace it with a Chief and Council elected under the Indian Act. This was against the wishes of the majority of the members of Six Nations. Even, today, the vast majority of the residents of Six Nations refuse to participate in Indian Act elections.

Until the mid 1990's almost all the Bands in Canada had Indian Act elections (sections 73-79). In this system, each member casts a secret ballot and the candidates with the most votes are elected. They hold office for two years. Where there is a dispute about the election, the parties 
must approach the Minister who will then make a recommendation to the federal Cabinet. The Cabinet will decide whether to call another election. If a person is guilty of a corrupt practice or accepting a bribe, it is the Minister of Indian Affairs who had the authority to declare that the councilor no longer holds office (section 78(2)(b)(iii)). Even in a case where a chief or councilor misses three consecutive meetings without authorization, it is the Minister who must declare that the person no longer holds office (section $78(2)(\mathrm{b})(\mathrm{ii}))^{7}$. The members of Council do not have the authority to make these decisions.

In an effort to exert more community control over elections, many First Nations began approving their own election codes and holding "custom elections" (section 2(1)- "council of the Band"). In order to move from Indian Act elections to "custom elections" First Nations must satisfy certain conditions. According to the "Conversion to Community Elections Policy" of Indian Affairs, the First Nation's electoral code must be approved by members either through a referendum or some other sort of "community approval" process. Some First Nations organized door-to-door canvasses to have members sign their approval of the code. The Department has the power to determine whether an initial code is satisfactory and in practice, Department officials will comment on the custom codes and require changes before approval.

Each custom election code is different. In some cases, the codes make minor changes to the Indian Act elections, such as lengthening the term of the Chief and Council from two years to three years. In other cases, the changes can be significant. Courts have held that custom elections need not need not be in writing, ${ }^{9}$ need not be by secret ballot and chiefs could be hereditary. ${ }^{10}$ For example, the Saulteau First Nation Government Law called for each of the five families on the reserve to elect a Headman by consensus. The five Headmen, in consultation with the Council of Elders, selects a Chief. ${ }^{11}$ The Huron-Wendat First Nation instituted a similar scheme, based on nominations from family circles. ${ }^{12}$ The Rousseau River Anishinabe First Nation split the governance between an elected Chief and Council and a "Custom Council" made up of representatives of family groupings. ${ }^{13}$ In almost all cases, disputes about elections are dealt with, not by Indian Affairs, but rather by some sort of Election Appeal Board made up of Band members.

In the case of elections, we can see that there has been a bit of a shift. Under the Indian Act elections, Indian Affairs had the final say on how elections were conducted and whether the elections could be appealed. First Nations that converted to custom elections have much more control over the process and a First Nation appeal tribunal decides the disputes.

\section{How to Create an Accountability Structure for Chief and Council}

The provisions discussed above show that the Minister of Indian Affairs and officials of the Department still have a great deal of authority. As we have seen, the Minister of Indian Affairs has almost unlimited power to disallow general by-laws as well as by-laws dealing with money. There is nothing in the Indian Act itself, which gives any guidance on how the power of the Minister is to be exercised. The danger is that the Minister could thwart the wishes of the community for inappropriate reasons. On the other hand, we can see that in making the by-laws, the Chief and Council are not given any guidance either. They are not required to consult the community or even give notice that they are going to pass a new by-law. 
When looking at reforms in a First Nation governance regime, then, the solution is not simply to take away the power of the federal government to disallow by-laws. Doing that will only address half the problem. The other half of the problem is to ensure accountability of Chief and Council to the members of the community.

The discussion above has shown that there is a movement in recent years to reduce the power of the Minister of Indian Affairs and to increase the participation of members of the community. If this trend continues what will a First Nation governance system look like?

The Three Elements of an Accountability Structure

1. Community participation

2. Respect for core principles

3. Authority to certify and interpret laws and decisions

\section{Community Participation}

Members of the community should be able to actively participate. They should be able to suggest new laws, comment on proposals and have a say in changing laws. Not all laws are of equal importance and the degree of community participation could vary depending on the law that is being proposed. An important law, such as banning alcohol, could require a community meeting. Something that was more

routine, such as erecting a protective fence around a school, could simply require publication of a notice that the by-law was going to be voted on at a council meeting.

How could there be community participation in decisions about land use on reserve? While it may not be appropriate to have a community meeting before every decision, there are ways to build in community participation. For example, the community could be involved in developing a land use plan for the reserve and criteria for granting certificates of possession. For Band housing, many reserves already have Housing Committees made up of community members as well as representatives of Council. For a surrender of part of the reserve, the Indian Act already requires a community meeting and a vote (s.39).

Under the Indian Act, some sections provide for no community participation or notice at all. In the previous section I pointed out that the general powers (s.81) and the money powers (s.83) merely require a vote of Chief and Council at a meeting - nothing more. Consequently, a Chief and Council could pass a by-law on taxation or land use without informing anyone. The by-law would not be effective until there was approval from the Minister. But the Minister is not required to consult with anyone either. Therefore, it is conceivable that a community could wake up one morning subject to a by-law that had never been made public.

As we have seen, since the 1980's new law-making powers in the Indian Act require a greater degree of community consultation. In the alcohol control by-laws (s.85.1), there is a requirement that the by-law be approved by a vote of the majority of the people who attend a public meeting. This improves accountability, by requiring prior notice of the by-law and a public debate. The Minister of Indian Affairs does not have the power to disallow this by-law. One potential weakness of this procedure is that it does not say that any particular number of people needs to attend the meeting. It is possible, therefore, that a small group of people could decide to vote 
down an alcohol restriction by-law. In this type of by-law approval procedure, the community members have a responsibility to participate in the decisions so that the law is a true reflection of community interests.

There are a variety of ways for getting community participation. Voting by secret ballot, community meetings and door-to-door canvassing are the most common. There are other alternatives available as well, such as discussions in family circles with representatives of families meeting to reach consensus. Or for routine matters an announcement over the community radio, the First Nation web site or community newsletter could be sufficient.

\section{Respect for Core Principles}

Law-making is not simply about making rules that have the support of the majority of the voters. Accountability involves respect for core principles important to the cultural survival of the community. In mainstream Canadian society, many of these principles are embodied in the Charter of Rights in Freedoms in the Constitution. The main purpose of the Charter is to protect individual Canadians against the actions of governments. Values such as free speech, the rights to due process in criminal proceedings and freedom from discriminatory laws are included in the Charter. Since all federal legislation must conform to the Charter, by-laws made under the Indian Act must also conform to the Charter. This means that Band Councils cannot make bylaws that violate the Charter. For example, let us say that a Band Council passes a residency bylaw that discriminates against women. The women could challenge the by-law in Federal Court using the Charter of Rights and Freedoms.

The Federal Court has established another set of standards for the conduct of Chief and Council. In the mainstream justice system, there are standards that are not written down in advance, but developed case by case by judges - a modified oral tradition - that is called the "common law" or "judge-made law". One of the major principles developed by courts to guide decision-makers is the duty of decision-makers to act fairly. This is the law that courts have applied to Chief and Council in the granting of possession of reserve lands. As we have seen, there are no guidelines in the Indian Act on how Chief and Council are to make their decisions on this issue, but courts have said that people who are asked to leave their lands have a right to know the reasons they are being asked to leave and a right to have an opportunity to respond. ${ }^{14}$ In allotting lands for certificates of possession (s.20 (1)), the Chief and Council also have a duty to keep the best interests of the Band in mind.

... before making an allotment under s. 20(1), a council has a duty to consider the rights of other band members. That duty would require a balancing of the individual's request for the allotment, including the purpose for which the allotment would be used, with the best use the land could be put to for the band community. ${ }^{15}$

The question for First Nations as they move towards a First Nation governance regime is whether these standards are the most appropriate for the First Nation. The Charter of Rights and Freedoms, for example, has been criticized for being too "European" and too oriented to mainstream non-Aboriginal values, which stress individuality rather than community. ${ }^{16}$ Those First Nations who want to assert a right to self-government often argue that the Charter of Rights 
should not apply to their laws. Even if the Charter values are general enough to apply to the First Nation, are they the only standards that the Chief and Council should abide by?

Several First Nations have written their own constitutions to outline important principles for the conduct of both government and citizens. The Teslin Tlingit Constitution includes a principle for the protection of their Clans:

The Clan is the primary unit of social organisation and authority within the Teslin Tlingit Nation. The authority, responsibilities and traditions of the Clans must not be undermined or diminished. ${ }^{17}$

The Constitution of the Westbank First Nation begins with a set of principles for the interpretation of the constitution. One of the principles relates to culture.

Westbank Members value the need to respect, protect and promote their heritage, culture and traditions understanding that their traditions and practices change and that they continue to develop contemporary expressions of those traditions and practices. ${ }^{18}$

The Ta'an Kwach'an Council has an objective for the Constituion, to "encourage personal healing for the unity and wellness of our community". ${ }^{19}$

A First Nation governance regime could allow members to challenge actions of Chief and Council that do not conform to the core principles set out in the First Nation constitution. But what body should hear the challenge: a non-Aboriginal court or an institution established by First Nations? That is the issue addressed in the next section.

\section{Authority to Certify and Interpret Laws and Decisions}

It is natural that there will be differences of opinion on whether the proper procedures have been followed in making laws or whether the laws are consistent with the core principles of the community. An important component of a governance structure is the mechanism for certifying and interpreting the laws.

Under the Indian Act the Minister of Indian Affairs enforces many of the standards and procedures. In the provisions on developing membership codes, for example, the Minister must determine whether the band fulfilled the procedural requirements by giving notice and getting approval of the majority of the electors. If these conditions have not been met, the Minister will not approve the code. Likewise, the Department of Indian Affairs retains the power to prevent a Band from going to custom elections if there has been no referendum or other process approving the change in the election procedure.

In the mainstream justice system, courts also play an important role in ensuring that laws are properly enacted and conform to the principles in the Charter of Rights and Freedoms. A court can strike down a law, even if it is validly passed and supported by the majority of Canadians, if the law violates the principles in the Charter. First Nations would also want to ensure that there is a mechanism for controlling the actions of Chief and Council. For example, there could be a 
requirement that First Nation laws have to be consistent with the cultural traditions of the First Nation. A law that failed to meet these principles, even if the majority of the voters approve it, could be challenged.

For First Nations however, a fundamental question is whether it is appropriate to have the Department of Indian Affairs or the Federal Court as the main mechanism for ensuring compliance with process and with core First Nation principles. Would it be possible to have First Nation tribunals perform these functions?

First Nations who have developed custom election codes have attempted to keep decisionmaking in the community by creating electoral officers or election appeal tribunals to settle disputes about elections. This has removed some of the power from the Minister of Indian Affairs and allowed respected members of the community to resolve election disputes. At Akwesasne, Wewaikai (Cape Mudge) and Westbank, these internal mechanisms have apparently been successful in gaining the respect of the community. ${ }^{20}$

However, experience shows that internal mechanisms also have their own problems. For example, there may be difficulties in selecting an appeal panel, which is "neutral". ${ }^{21}$ One First Nation attempted to address this issue by requiring that one member of the Election Tribunal be a person from outside of the community. They appointed their lawyer, but even that lawyer was challenged for having a conflict of interest because of the work she performed for one of the candidates in the election. ${ }^{22}$ In order to avoid conflicts of interest and bias, other mechanisms could be considered. Individual First Nations could agree to be bound by decisions of a regional or even national tribunal made up of respected First Nations individuals. Such a body could remove the power of the Department of Indian Affairs while ensuring that important functions related to accountability could be performed as a check on the power of individual Chiefs and Councils.

First Nations should also ensure that First Nation laws are well known. This could be done through keeping a record of all by-laws in the First Nation office or publishing them on the internet. If there are laws that are more appropriately recited orally, they could be recorded and made available at the First Nation office or placed on the internet.

\section{Summary: First Nation Governance}

In this paper, we have reviewed accountability mechanism found in the Indian Act for lessons on how to move toward a First Nation governance regime.

First, it is clear that there should be community involvement when laws are made.

$\checkmark$ The degree of community participation could vary, depending on the importance of the law concerned. The participation may include consultation, community meetings and votes.

$\checkmark$ The type of consultation could also vary. Communities could consider innovative ways to provide for participation, including meetings of family groupings and door-to-door consultations. 
Second, communities could consider identifying their own core principles.

$\checkmark$ All laws and decisions could be made conform to the core principles of the First Nation, such as the respect for the culture of the First Nation or respect for Elders.

$\checkmark$ The Charter of Rights and Freedoms could also apply, depending on the structure of the First Nation governance regime. There are also decisions of the courts requiring that the Chief and Council act fairly that could also be made to apply. ${ }^{23}$

Third, communities should consider which body should interpret the laws and certify that laws have been validly enacted.

$\checkmark$ Internal mechanisms such as an appeal tribunal made up of respected Elders or other members in the community, or of a regional body made up of representatives from other First Nations, could fulfill this function.

$\checkmark$ Communities should decide whether they wish to continue to be able to appeal to a federal or provincial court. All self-government agreements provide for internal mechanisms with appeals to the courts but there are ways to limit court involvement if that is desired.

Attached is a table that illustrates the degree to which the Indian Act regime and the First Nation governance regime fulfill the three components of accountability in law making and decisionmaking.

\section{Conclusion}

This discussion began by observing that there was validity to two contradictory claims about the Indian Act. First, the Indian Act did not give Chiefs and Councils enough power. Second, that the Indian Act gave Chiefs and Councils too much power. We have seen through a discussion of the structure of the Indian Act that the problem is that the Minister of Indian Affairs had too much power to override decisions of Chief and Council and that the Indian Act did not require Chief and Council to be accountable to the community.

First Nations in Canada are already looking at ways of addressing these two problems. Many of the negotiated self-government agreements remove much of the power of the Department of Indian Affairs and require more accountability by Chief and Council to community members. Even Bands under the Indian Act are moving in that direction. This is particularly true for First Nations that are creating their own custom election codes. The creation of the Code requires a great deal of community participation and the monitoring of elections is taken away from Indian Affairs and placed in the hands of First Nation tribunals.

First Nations have developed tools for balancing the powers of Chief and Council, the community members and a First Nation tribunal. It now remains for each First Nation to determine the best balance for their community.

$* * * * * * * * * * * * * * * * * * * * * * * * * * * * * * * * * * * * * * * * * * * * * * * * * * * * * * * * * * * * * * * * * * * * * * * * * * * * * * * *$ Structure of Accountability Table 


\begin{tabular}{|c|c|c|c|}
\hline & $\begin{array}{l}\text { Community } \\
\text { Participation * }\end{array}$ & Respect for Core Principles $* *$ & $\begin{array}{l}\text { Authority to Certify and } \\
\text { Interpret Laws } * * *\end{array}$ \\
\hline \multicolumn{4}{|l|}{ Indian Act Regime } \\
\hline $\begin{array}{l}\text { Allotment of certificates } \\
\text { of possession (s.20) }\end{array}$ & None required & Charter of Rights and Freedoms & $\begin{array}{l}\text { Unlimited power of } \\
\text { Minister of Indian } \\
\text { Affairs }\end{array}$ \\
\hline $\begin{array}{l}\text { Allocation of Band- } \\
\text { owned housing }\end{array}$ & None required & Charter of Rights and Freedoms & Minister not involved \\
\hline $\begin{array}{l}\text { General and money by- } \\
\text { laws (sections } 81 \text { and } \\
83 \text { ) }\end{array}$ & None required & Charter of Rights and Freedoms & $\begin{array}{l}\text { Unlimited power of } \\
\text { Minister of Indian } \\
\text { Affairs }\end{array}$ \\
\hline Alcohol by-law (s.85.1) & $\begin{array}{l}\text { Publication and } \\
\text { community } \\
\text { meeting }\end{array}$ & Charter of Rights and Freedoms & $\begin{array}{l}\text { Limited power of } \\
\text { Minister }\end{array}$ \\
\hline Membership code (s.10) & $\begin{array}{l}\text { Publication, } \\
\text { community } \\
\text { meetings and } \\
\text { vote }\end{array}$ & Charter of Rights and Freedoms & $\begin{array}{l}\text { Limited power of } \\
\text { Minister }\end{array}$ \\
\hline Custom elections & $\begin{array}{l}\text { Community } \\
\text { consensus }\end{array}$ & $\begin{array}{l}\text {-Charter of Rights and Freedoms } \\
\text {-First Nation core principles }\end{array}$ & First Nation Tribunal \\
\hline \multicolumn{4}{|l|}{$\begin{array}{l}\text { Possible First Nations } \\
\text { Regime }\end{array}$} \\
\hline First Nation laws & $\begin{array}{l}\text { Appropriate } \\
\text { community } \\
\text { participation }\end{array}$ & $\begin{array}{l}\text {-First Nation Core Principles } \\
\text {-Charter of Rights and } \\
\text { Freedoms? }\end{array}$ & First Nation Tribunal \\
\hline
\end{tabular}

\section{Notes}

* Community participation - There are different mechanisms available ranging from a simple general meeting to referenda with high approval requirements

** Respect for core principles - The Charter of Rights and Freedoms applies to all federal legislation. Whether it also applies in a First Nation regime depends on how that regime is constructed.

*** Authority to certify and interpret laws - In all cases under the Indian Act there is access to the Federal Court, whether or not the Minister or Department of Indian Affairs also has powers to make decisions. Access to courts in a First Nations regime will depend on how that regime is constructed. 


\section{Endnotes}

${ }^{1}$ Canada, Report of the Royal Commission on Aboriginal Peoples, Volume 1, Part 2, chapter 9 “The Indian Act”, at p.70 ( http://www.ainc_inac.gc.ca/ch/rcap/)

${ }^{2}$ This statement is a bit of a simplification. The First Nation membership code must conform to certain substantive requirements set out in the Indian Act. For example, the codes must allow Bill C-31 women to be members. If these requirements are met, the Minister cannot disallow the membership code. This is very different from the Minister's powers to disallow Band by-laws. For by-laws, the Minister does not even have to give reasons for deciding to disallow.

${ }^{3}$ A vote of the Band is not required: Joe v. Findlay, [1987] 2C.N.L.R. 75 (B.C.S.C.)

${ }^{4}$ Although the Indian Act does not explicitly give the Band Council power to allocate land on a temporary basis, courts have recognized that Bands have authority to do this: McMillan v. Augustine, [2004] 3 C.N.L.R. 170 (N.B.Q.B.) and Seabird Island Indian Band v. McNeil-Bobb [2000] B.C.J. No. 1133 (B.C.S.C.)

${ }^{5}$ Disputes have gone to court and judges have attempted to set out some guidelines. For a summary of the law, see the cases listed under s.20 in Shin Imai, The Annotated Indian Act and Aboriginal Constitutional Provisions, Toronto: Thomson Carswell.

${ }^{6}$ Twinn v. Canada (Minister of Indian Affairs and Northern Development), [1987] 3 C.N.L.R. 188 (Fed. Ct. )

${ }^{7}$ For court cases on this issue see under sections 78 and 79 of the Indian Act in Shin Imai, The Annotated Indian Act and Aboriginal Constitutional Provisions, Toronto: Thomson Carswell.

${ }^{8}$ It should be noted that Chief and Council elected under "custom elections" are recognized under the Indian Act and by the government as the official administrators for the Band. Therefore, they have the powers to make decisions, pass by-laws and enter into funding arrangements. Chief and Council elected in custom elections can be different from traditional governance structures, which are not recognized by the government. For example, on the Six Nations reserve in Ontario there is a very strong following for the traditional government of the Haudenosaunee. The traditional Council was removed and the elected system imposed on Six Nations in 1924. The vast majority of the people at Six Nations continue to refuse to vote in federal elections and do not participate in votes for the Indian Act Chief and Council. The Haudenosaunee government is not recognized by the Federal government and does not hold any powers under the Indian Act.

9 Salt River First Nation 195 v. Marie, [2004] 1 C.N.L.R. 319 (F.C.A.); Francis v. Mohawk Council of Kanesatake, [2003] 3 C.N.L.R. 86 (Fed. Ct.)

${ }^{10}$ Crow v. Blood Indian Band Council, [1997] 3 C.N.L.R. 76 (Fed.Ct.)

${ }^{11}$ Napoleon v. Garbitt, [1997] B.C.J. 1250 (B.C.S.C)

${ }^{12}$ Gros-Louis v. Conseil de la Nation Huronne-Wendat, [2000] F.C.J. No. 1529 (Fed.Ct.)

${ }^{13}$ Roseau River Anishnabe First Nation v. Roseau River Anishnabe First Nation, [2003] 2 C.N.L.R. 345 (Fed.Ct.). The Gitga' at Tribe of the Tsimshian Nation also had a two tier system of government with a non-elected Clan Council and elected Village Council (Clifton v. Benton, 2005 F.C. 1030 (Fed.Ct.)

${ }^{14}$ Sheard v.Chippewas of Rama First Nation, [1997] 2 C.N.L.R. 182 (Fed.Ct.)

${ }^{15}$ Lower Nicola Indian Band v. Trans-Canada Displays Ltd., [2000] 4 C.N.L.R. 185 (B.C.S.C.), at para.155

${ }^{16}$ Several First Nation writers have commented on this issue. See for example, Candace Metallic and Patricia Monture-Angus in borderlands e-journal,Volume 1 Number 2, 2002 ( 
http://www.borderlandsejournal.adelaide.edu.au/vol1no2_2002/metallic_angus.html)

First Nations considering litigation under the Charter should be very careful to scrutinize the consequences embedded in that instrument. ... The failure to do so may result in a potential misdirection of section 35(1) toward a rights paradigm driven by a culture that values individualism (versus some form of discussion about communal or collective rights). This dichotomy is not helpful.

${ }^{17}$ The Teslin Tlingit Constitution can be found at www.ttc-teslin.com/

${ }^{18}$ The Westbank First Nation Constitution can be found at www.wfn.ca

${ }^{19}$ The Ta'an Kwach'an Constitution can be found at dwww.taan.ca/constitution.html

${ }^{20}$ Personal communication from lawyer Micha Menczer

${ }^{21}$ In Lavallee v. Louison, [1999] F.C.J. No. 1350 (Fed.Ct.) the court held that the size of the Band had to be taken into consideration in deciding whether there was a reasonable apprehension of bias. See also Willier v. Sucker Creek Indian Band, [2002] 4 C.N.L.R. 298 (Fed.C.A.) where the Electoral Officer could not find enough "neutral" members to make up an Appeal Tribunal.

22 Sweetgrass First Nation v. Gollan, 2006 CarswellNat 1657,2006 FC 778(Fed.Ct.)

${ }^{23}$ In Crow v. Blood Band [1997] 3 C.N.L.R. 76 Crow claimed that there was a violation of the Charter of Rights and Freedoms in a custom election code. The Federal Court questioned whether the Charter applied to custom elections. In this case, it was not necessary to decide whether the Charter applied or not so no decision was made on that point. If custom elections are an expression of an inherent power of the First Nation., as was found in Bone $v$. Sioux Valley Indian Band No. 290 [1996] 3 C.N.L.R. 54 (Fed.Ct.), the Charter may well not apply. See also Kent McNeil "Aboriginal Governments and the Charter: Lessons from the United States" (2002) 17 Can.J.Law and Soc. 73-105. 